\title{
ANAESTHETIC MANAGEMENT OF ELECTRICAL BURN IN A PATIENT WITH SICKLE CELL DISEASE
}

\section{J. Latorre, C.M Castro Arias, M. López Martínez, A. Kollmann Camaiora, E. Guasch Arévalo, F. Gilsanz Rodríguez}

Hospital Universitario La Paz, Dept of Anaesthesia, Madrid, Spain

BACKGROUND Sickle cell disease (SCD) and electrical burn injuries are unique entities.

SCD is an inherited condition due to a mutation in the $\beta$-globin gene.

Electrical burns result in morbidity higher than expected based on burned area.

\section{CASE REPORT}

- 19 years old man, native of Equatorial Guinea, with a history splenectomy, admitted due to high-voltage electric burns.

- On arrival at the hospital he was stable. He had $2 \%$ burned body surface to deep dermis.

- Laboratory analysis showed normocitic anaemia (Hb 8,4 g/dL; MCV 91.3fL).

- The haematology consultant observed poikilo-drepanocytosis, target cells and schistocytes on blood smear, being diagnosed with SCD.

- Had an acute sickle cell exacerbation with abdominal pain that was controlled with adequate hydration and correction of anaemia.

- Required transfusions to maintain a $\mathrm{Hb}$ up to $7.5 \mathrm{~g} / \mathrm{dl}$.

\section{ANAESTHETIC MANAGEMENT FOR BURNS} DEBRIDEMENT

General anaesthesia, with a laryngeal mask and standard monitoring.

- Inspired oxygen fraction was set to $\mathrm{SatO}_{2}>95 \%$.

- Adequate hydration.

- Fluid heater and thermal blanket.

- Morphine chloride and paracetamol for postoperative analgesia.

\section{DISCUSSION}

- Avoid triggers of acute attacks, specially: $\underline{\text { HYPOXIA, DEHYDRATION, PAIN AND COLD }}$ 